\title{
The Influences of Effectiveness, Competitive Advantages and Market Accessibility on SME Performance in Malaysia.
}

\author{
Razleena Razali ${ }^{1, *}$, Ummi Naiemah Saraih ${ }^{1}$, Mohd Shahidan Shaari ${ }^{1}$, Mohd Juraij Abd Rani ${ }^{1}$ \\ Aidanazima Abashah ${ }^{1}$ \\ ${ }^{1}$ School of Business Innovation and Technopreneurship, Universiti Malaysia Perlis (UniMAP), Malaysia
}

\begin{abstract}
The advent of online business has changed the pattern of doing business recently. This circumstance puts more pressure on SMEs to sustain their position in the fiercely competitive market. Unlike multinational companies, SMEs have several inevitable weaknesses in terms of planning strategy, technology exposure as well as resources that serve as a stumbling block to their better and competitive performance. Thus, online business appears to be a new medium to enhance the performance. Therefore, this study aims to investigate the influences of effectiveness, competitive advantage and market accessibility on SME performance in Malaysia. This study uses cross sectional study which focuses on SMEs that are engaged in online businesses. 200 questionnaires were distributed particularly to SMEs in food and beverages (F\&B); apparel and textile (A\&T); and health and cosmetic (H\&C) industries in Malaysia. Results indicate that market accessibility is the only variable which has an influence on entrepreneurs in online businesses within SMEs performance $(\beta=.48, p<.01)$. This study can shed light on SME performance to the government. For example policy makers can enhance programs and initiatives in the SMEs Master Plan for the year 2012-2020. This study also helps the SMEs avail themselves of the online business opportunity in enhancing their performance. Therefore, the implication of market accessibility in influencing SME performance is discussed in this study.
\end{abstract}

Keywords: Effectiveness; competitive advantage; market accessibility; online business; SME performance

\section{Introduction}

SMEs are one of the country's backbones in driving Malaysian economic growth close to other developed countries. Therefore, SMEs is encouraged to find ways such as engage in online business in ensuring their business remains competitive in the market. Online business helps firms become cost effective and at the same time improve productivity and quality. Thus, the online business appears to be a new medium to enhance business, especially in achieving better performance ad sustainability.

The idea of online business starts takes place and gradually replacing the traditional business system and some of business uses it as the channel of communication for their business, especially in creating a better and effective relationship with the customer and other stakeholders. In addition, the online business can be done faster and cost effective to the customer as well as for the businesses. Hence, that is why business starts chooses to go online, especially for SMEs in a certain business field such as food and beverages textile and apparel, as well as beauty and cosmetic.
According to [1], although $90 \%$ SMEs in Malaysia are using personal computers in their businesses, the IT implementations are still at the fundamental stage. The result is parallel with a research finding by [2] where the SMEs usage of online business among Malaysian SMEs is still low. To enhance the usage of online business, [3] has proposed online business or e- commerce adoption and implementation in SMEs business. This is because; the increasing of world population and internet user can be one of the opportunities for Malaysian SMEs to gain and improve their business performance. Besides, online business gives opportunity to improve SME's performance in domestic and international market. Unlike multinational companies, most of SMEs especially in Malaysia has weaknesses in term planning strategy, technology exposure as well as resources such as capital that become barriers for their expansion of business and operation abroad. Thus, the easiest and fastest strategy to reach the market is through online business strategies [4].

According to [5], online business will change Asia more than it changes the U.S. This shows that online business plays an important role to help the company change the way of doing business with local and overseas client and agents more cost effectively. This

\footnotetext{
* Corresponding author: razleena@unimap.edu.my
} 
statement supports this study where SMEs in Malaysia is part of Asia and these SMEs will deal with the advancement of technology such as online business even though they will face a lot of challenges difficulties in implementing the online business. Hence, with the current scenario and justification made earlier, the primary aim of this study is to reveal the influences variables to the SME performance by the SMEs that already implemented the online business in their business.

\section{Literature Review}

\subsection{SME Performance}

The performance and growth of SMEs is a major driver and indices for the level of industrialization; modernization; urbanization, gainful and meaningful employment for all those who are able and willing to work, equitable distribution of income, the welfare, income per capital and quality of life enjoyed by the citizenry [6].

Performance is a widely used concept in many areas. Usually, performance is a measure of how well a mechanism or process achieves its purpose. In enterprise management, [7] defines an organization's performance as how well the organization is managed and "the value the organization delivers for customers and other stakeholders." For the purposes of this research, SME performance is related to sales based performance and organizational based performance, which is also focused on the financial part such as profitability, growth, cost reduction, market share and Return on Investment (ROI) and non-financial part which is customer satisfaction, employee satisfaction and productivity as well as innovation.

Studies have found that there is a significant relationship between competitive advantage and the sales-based performance of SMEs, when sales-based performance was measured by the level of sales revenue, profitability, return on investments, productivity, product added value, market share and product growth [8]. Additionally, other studies also further illustrate a significant relationship between effectiveness and the organizational-based performance of organizations, when organizational-based performance was measured by the emphasis on efficient organizational internal processes, customer satisfaction, employee development and job satisfaction [4].

Competitive advantage and business performance are two different constructs with an apparently complex relationship [9]. Since the 1980s, many scholars began to study online business on marketing activities of SMEs. Most scholars believe that with the development of internet technology, the performance of online business applications in SMEs has a significant promotion effect; in addition, some scholars also found some problems in the implementation of online business enterprises, and put forward the path and strategy of enterprises to optimize the mode of online business $[10,11]$. A study of [12] investigated the impact of information technology on the competitive environment, and how to use internet technology to improve the competitive advantage of enterprises. The finding was the internet technology promotes the enterprises to develop new business, and bring more business opportunities for the enterprise.

As analyzed by [13], more than 40 SMEs from Canada, China, Japan and Mexico developed the online business in the international market. The result shows that online business can reduce product and service cost in a unique way, and combine the information and capital at the same time, then enhance enterprise effectiveness and competitive advantage. This is aligned with most previous studies on SMEs which is online business give a lot of impact towards SMEs' performance and it's just the SMEs do not take full charge of the opportunity of the online business. As discussed, the online businesses create effective business, competitive advantage and business have more market accessibility in domestically and internationally which directly associated with business performance. Therefore, studying SME performance would provide insights into the existing literature in the domain of effectiveness, competitive advantage and market accessibility.

\subsection{Effectiveness}

The key of online business effectiveness is its ability to target the right customers, cost efficiency and analytics. Adoption of online business is not only strengthening growth possibilities, but also creating a network with all other business in the world, can have cooperation, and can improve quality and knowledge [14].

According to [15], online business is important to SMEs because it will help to develop the efficiency of the organization. Several studies finding shows that use of e- business increase sales and can reduce business costs and improve productivity of the business [16]. The use of online business can improve business competitiveness with the internet providing numerous opportunities for SMEs to compete equally with large corporations [17]. The study conducted by [18] argued that the flow of information in an organization is the blood life of any business operating unit irrespective of its size. It is commonly accepted that online business provides many potential benefits to organizations so as to make them more efficient, effective and competitive [19].

Meanwhile, [3] suggests that SMEs should implement online business since it's really effective for business productivity and SME performance especially in online services. Additionally, online business is the kind of technology that enables flexibility and costeffectiveness is now considered a requirement for SMEs 
in the current competitive global market. By the implementation, it adds value to the company in its dayto-day business transactions. Realizing the effectiveness of online business to business, SMEs are encouraged to involve more with technology. This is helping SMEs to become more effective in dealing with the challenging world [3].

\subsection{Competitive Advantage}

Competitive advantage is a base for a good strategy, and a good one creates competitive advantage [20]. Recently, [21] claim that IT and the Internet in particular can create a competitive advantage and improve performance and competitiveness and also it has been argued that achieving a position of competitive advantage is a necessary precursor to a SME significant performance. One of the ways for companies to be ahead of its competitor is to stay updated and in-trend is via engaging in online business. Online business is one of the strategies of the company and SMEs implement in their business nowadays.

Having online presence can be beneficial for many SMEs with adequate preparation prior to its implementation. They gain competitive advantage through online business. The online business can be the resourceful medium or platform for SMEs to gain competitive advantage against its competitor. This can be supported by the theory of Resource- Based View (RBV). RBV stipulates that the fundamental sources and drivers of competitive advantage and superior performance are chiefly associated with the attributes of resources and capabilities, which are valuable and costly-to-copy [22].

In literature on the other industry such as tourism and hospitality, result indicates the primary role of IT in the hotel industry is to improve its productivity and lead to a better SME's performance. Many studies on tourism and hospitality industry claim that ICT, especially online business is one of a competitive advantage factors. This can be the proof that online business gives competitive advantage to the companies. The existence of website, application for mobile and advertising via social media by this industry shows the importance of online business.

Online business has received much attention in the last two decades due to its effects and potential impact on organizational success especially for SMEs. However, according to [23], the degree to which a smallto SMEs may experience the internet as a threat or opportunity in developing business strategies will depend on industry and firm factors such as: The small firm's technical and internet knowledge, rate at which the market is growing, pace of innovation and change in the industry, technical and internet strengths of the larger competitors, sources of competitive advantage for the small business, strategic intent of the larger competitors, structure of the industry in which the firm competes.

\subsection{Market Accessibility}

Market access can be defined as the process to ensure that all appropriate patients who would benefit get rapid and maintained access to the brand, at the right price. The goal of business is to gain wider market accessibility domestically, internationally and globally so that their business can be a legacy or sustainability in the world besides making a profit and achieve business growth. Thus, one of the ways to make these goals become reality is through e- business or online business.

For many SMEs, the unpredictability of doing business and the complexity of procedures and regulations in many countries are perceived as major barriers. Furthermore, access to finance, new technology and good, reliable infrastructure, especially for communications and logistics, are all special problems for growth-oriented SMEs [24]. According to [25], the internet can be a critical factor in enhancing a firm's market reach and operational efficiency. It has been agreed by many authors that invest in, and proper utilization of online business is a major way of improving productivity among the vital SME sector.

Application of online business is found to have a significant positive relationship with increased performance of SMEs in Malaysia. This result is consistent with the prior research findings by [26] where an application of information technology will enhance the overall performance of SMEs in Malaysia. The adoption of online business will assist an organization in storing information as well as communicating with their international customer, suppliers and business partner who will facilitate business transaction oversea. As a result, it will lead to a better performance in reducing the operating expenses as a whole. Online businesses also help to facilitate SMEs to penetrate foreign markets. Basically, they have the potential market in their vision and online business helps to execute this vision into reality and an achievement. This is because, when market size increases, the benefits of internationalization will increase [27].

Given all the literature, the specific hypotheses are developed as follows:

$\mathrm{H}_{1}$ : There is a significant relationship between effectiveness and SME performance.

$\mathrm{H}_{2}$ : There is a significant relationship between competitive advantage and SME performance.

$\mathrm{H}_{3}$ : There is a significant relationship between market accessibility and SME performance.

\section{Methodology}

The population of this research included SMEs that already implemented online business in their business from three (3) types of industries which are food and beverages textile and apparel, as well as beauty and cosmetic. This study utilized the quantitative method (eg. questionnaire). Questionnaires are distributed 
randomly for 200 respondents. The SPSS software (version 22) has been used for the statistical analysis. The instruments used for all variables (performance, effectiveness, competitive advantage and market accessibility) have been adapted from previous measurements. SMEs need to respond their opinion towards four variables of performance (12 items) effectiveness (9 items), competitive advantage ( 8 items) and market accessibility (13 items).

\section{Results and Discussions}

Table 1 presented the response rate based on the total number of distributed questionnaires. Out of 200 distributed questionnaires, only $101(50.5 \%)$ of the returned questionnaires have been used for further analysis.

Table 1. Response Rate

\begin{tabular}{|l|c|c|}
\hline & Figures & Percentage \\
\hline Number of Distributed Questionnaire & 200 & $100 \%$ \\
\hline Number of Returned Questionnaires & 109 & $54.5 \%$ \\
\hline Number of Usable Questionnaire & 101 & $50.5 \%$ \\
\hline
\end{tabular}

\subsection{Respondents' Background}

Most of the respondents who participated in this study were female $(55.4 \%)$, it meant that and the remaining of the repondents were male $(43.6 \%)$. In term of business experiences, $49.5 \%$ of respondents have 1 to 5 years of business experience. This percentage was followed by $33.7 \%$ of respondents have 6 to 10 years of business experience. About $9.9 \%$ of respondents have 11 to 15 years of business experience and $5.9 \%$ of respondents have 16 to 20 years of business experience. The lowest percentages of responses $(1.0 \%)$ are obtained from respondents who have more than 20 years of business experience.

In term of industry's type, $48.5 \%$ of respondents came from food and beverage (F\&B) industry; $32.7 \%$ of respondents from the apparel and textile (A\&T) industry; $10.9 \%$ of respondents from health and cosmetic (H\&C) industry and the remaining $7.39 \%$ of respondents were from other industries.

In the aspect of respondents' perception towards their abilities to sell the products in the foreign market, most of respondents (67.3\%) ticked 'yes' for the answer. This percentage was followed by $25.7 \%$ of the respondents ticked 'in the process'. A small percentage ofv $6.9 \%$ ticked 'no' for the answer.

\subsection{Reliability Analysis}

The Cronbach's alpha values are reported at .85 for effectiveness, .84 for competitive advantage and .92 for market accessibility. As for the SME performance, Cronbach's alpha value is reported at .94. According to [28] the Cronbach's alpha values showed that all of the variables are good to excellent in this study.

\subsection{Mean and SD Analyses}

In this study, the interpretation of mean scores has been referred to the previous authors [29]. According to these authors, the mean scores ranged from low (1.00-2.00), moderately low (2.01-3.00), moderately high (3.01-4.00) to high (4.01-5.00). As presented in Table 1, the mean value for SME performance was 4.01. Therefore, high acceptance is observed for this variable. Almost similar means score is recorded for effectiveness and market accessibility; 4.02, and 4.05. Competitive advantage has been recorded to have the lowest mean score at 3.73. However, moderately high acceptance is found for this variable.

Table 2. Mean and SD Values

\begin{tabular}{|l|c|c|c|}
\hline Variables & $\mathrm{N}$ & Mean & SD \\
\hline SME Performance & 101 & 4.01 & .48 \\
\hline Effectiveness & 101 & 4.02 & .44 \\
\hline Competitive Advantage & 101 & 3.73 & .54 \\
\hline Market Accessibility & 101 & 4.05 & .55 \\
\hline
\end{tabular}

As for the SD analysis, it is noted that the SD values for SME performance (.48), effectiveness (.44), competitive advantage (.54) and market accessibility (.55) were also high.

\subsection{Correlation Analysis}

Pearson correlation coefficient $(r)$ is a technique to determine the relationship between two quantitative and continuous variables. It measured the strength of the association between the variables. In this study, the correlation analysis had been run to determine the interdependency between SME performance, effectiveness, competitive advantage and market accessibility.

As presented in Table 3, low correlation is observed between SME performance and effectiveness $(\mathrm{r}=.37, \mathrm{p}<.01)$. Next, moderate correlations are found between SME performance and competitive advantage $(\mathrm{r}=.43, \mathrm{p}<.01)$ and between SME performance and market accessibility $(\mathrm{r}=.58, \mathrm{p}<.01)$.

Also, moderate correlations are remarked for relationships between effectiveness and competitive advantage $(\mathrm{r}=.67, \mathrm{p}<.01)$, effectiveness and market accessibility $(\mathrm{r}=.63, \mathrm{p}<.01)$ and between competitive advantage and market accessibility $(\mathrm{r}=.66, \mathrm{p}<.01)$. In sum, all correlations are reported as significantly and positively related between each other.

Table 3. Correlation Analysis

\begin{tabular}{|l|c|c|c|c|c|}
\hline \multicolumn{1}{|c|}{ Variables } & $\mathrm{N}$ & 1 & 2 & 3 & 4 \\
\hline 1. SME Performance & 101 & - & & & \\
\hline 2. Effectiveness & 101 & $.37^{* *}$ & - & & \\
\hline $\begin{array}{l}\text { 3. Competitive } \\
\text { Advantage }\end{array}$ & 101 & $.43^{* *}$ & $.67^{* *}$ & - & \\
\hline $\begin{array}{l}\text { 4. Market } \\
\text { Accessibility }\end{array}$ & 101 & $.58^{* *}$ & $.63^{* *}$ & $.66^{* *}$ & - \\
\hline
\end{tabular}

**Correlation is significant at the 0.01 level (2-tailed) 


\subsection{Regression Analysis}

As presented in Table 4, 35.0\% of the variance in SME performance is explained by effectiveness, competitive advantage and market accessibility $\left(\mathrm{R}^{2}=.35\right)$. To further clarify, the remaining of $65.0 \%$ of variance in entrepreneurial intention among these respondents is explained by the other variables. In addition, the adjusted $\mathrm{R}^{2}$ value also taken into account as .33 .

Based on the results, only market accessibility is positively associated with SME performance $(\beta=.48$, $\mathrm{p}<.01)$. Thus, this implied that only market accessibility is significantly related to SME performance among respondents in this study. Therefore, $H_{3}$ : There is a significant relationship between market accessibility and $S M E$ performance is supported in this study.

Table 4. Regression Analysis

\begin{tabular}{|c|c|c|}
\hline \multirow{2}{*}{ Variables } & \multicolumn{2}{|c|}{ SME Performance } \\
\cline { 2 - 3 } & Beta & Sig. \\
\hline Effectiveness & -.05 & .72 \\
\hline Competitive Advantage & .09 & .39 \\
\hline Market Accessibility & .48 & .00 \\
\hline \multicolumn{2}{|c|}{$\mathrm{R}^{2}=0.35$} \\
Adjusted $\mathrm{R}^{2}=0.33$ \\
$\mathrm{~F}=17.121$ \\
**Correlation is significant at the .01 level (2-tailed
\end{tabular}

Conversely, this study found that effectiveness $(\beta=-.05, \quad p>.01)$ and competitive advantage $(\beta=.09$, $\mathrm{p}>.01)$ are insignificantly related with SME performance among the respondents in this study. Thus, $H_{1}$ : There is a significant relationship between effectiveness and SME performance; and $\mathrm{H}_{2}$ : There is a significant relationship between competitive advantage and SME performance are not supported respectively in this study.

\section{Conclusions}

The results of this study presented that the level of SME performance in this study was in the high indications with the mean value reported at 4.01. Not only that, the level of effectiveness and market analysis was also high with the mean values reported at 4.02 and 4.05 each. A moderately high level of competitive advantage is reported at 3.73 .

As presented in Table 3, market accessibility is positively associated with SME performance $(\beta=.48$, $\mathrm{p}<.01)$. Therefore, only $H_{3}$ : There is a significant relationship between market accessibility and SME performance is supported in this study.

Based on the results, it can be concluded that by increasing the level of market accessibility within the online business entrepreneurs, the future level of SME performance can be enhanced. In the theoretical perspective, these findings had been consistent with the previous findings as reported by several authors $[25,26$, 27, and 28]. For example, [26] pointed out that internationalization is important for greater market access by SMEs for their sustainability strategy. In addition, the Internet which included of the online business can be a critical factor in enhancing SME market reach and its operational more efficiency. It has been agreed by many authors that invest in, and proper utilization of ICT is a major way of improving market accessibility among the vital SME sector. As a conclusion, this study presented that the online business created the entry mode by the market accessibility and it was positively and significantly related to SME performance.

In the practical perspective, the appropriate bodies such as policy maker or government possibly initiate and enhance appropriate policies and programs to help SME to utilize the online business presence and advantages. It can be enhanced by taking some initiatives to ensure both entrepreneurs and customers have access to the new technology by providing the strong and reliable infrastructure, particularly as a medium for entrepreneurs-customers interaction. These initiatives could ensure the existence of market accessibility for the current online business entrepreneurs in Malaysia and assist the online entrepreneurs to go further in the global market accessibility.

Also, this study provides awareness to the SME regarding the opportunities created by online business towards their business performance. The performance could be in term of satisfied customer and supplier relations, personnel, quality, flexibility, and planning.

Having respondents from SMEs industry in this study was not an easy process since not all online business entrepreneurs in this industry wanted to cooperate in providing their responses. Furthermore, it took about 2 to 3 months for the respondents to give their responses. Other than the large sample size, the researchers would like to propose for the future researchers to look on the other type of SME industry which focused on the services.

\section{References}

1. Hor, R. The Sun. SMI association launch E-SMI program (2001)

AvailableWWW:http://asia.internet.com/Sun,\%20S

MI\%20Association/Launch/ SMI/Program.

2. N. Muhd. NA Rahman et.al. The implementation of e-commerce application in bumiputera Small and Medium Enterprises (SMEs) in Malaysia, 2(2), 101110 (2013)

Available online at www.managementjournal.info34

3. SME Corp. Malaysia. (2013). [Online] Available:http://www.smecorp.gov.my/vn2/node/37.

4. Chelliah, S., Sulaiman, M., \& Yusoff, Y. M. Internationalization and performance: Small and Medium Enterprises (SMEs) in Malaysia. International Journal of Business and Management, 5(6), 27-37 (2010) 
5. Rao, M. "E-business will change Asia more than it changes the U.S." (2006) http://www.indiainfoline.com/nevi/inwi/mm52.html

6. Eniola, A. A. The role of SME firm performance in Nigeria. Arabian Journal of Business and Management Review, 3(12), 33-47 (2014)

7. Moullin, M. "Defining performance measurement." Perspectives on performance 2(2), 3 (2003)

8. Wang, Y., \& Lo, H. Customer-focused performance and the dynamic model for competence building and leveraging: A Resource-Based View. Journal of Management Development, 22(6), 483-526 (2003)

9. Ma, J.X., Buhalis, D. \& Song, H. ICTs and internet adoption in China's tourism industry. International Journal of Information Management, 23(6), 451-467 (2007)

10. Kim, D., Cavusgil, S.T., Calantone, R.J. Information system innovations and supply chain management: Channel relationships and firm performance, 34, 4054 (2006)

11. Tornatzky, L.G.; Fleischer, M. The processes of technological innovation; Lexington Books: Lexington, MA, USA, 145-156 (1990)

12. Kim, D.; Cavusgil, S.T.; Calantone, R.J. The role of information technology in supply-chain relationships: Does partner criticality matter? J. Bus. Ind. Mark, 20, 169-178 (2005)

13. David, A.J., Lorna, W. The e-business capability of small and medium sized firms in international supply chains. inf. syst. e-bus. manage., 2, 223-240 (2004)

14. Barba S.V, María D.P, Martínez R., Ana I.J.Z. Drivers, benefits and challenges of ICT adoption by Small and Medium Sized Enterprises (SMEs): A Literature Review, 5, 103-114 (2007)

15. Wen Z., King J. and Jaska P. ICT and SMES in developing countries The IABPAD Conference Proceedings Dallas, Texas, April 24-27 (2008)

16. Ashrafi, R., \& Murtaza, M. Use and impact of ICT on SMEs in Oman. Electronic Journal Information Systems Evaluation, 11(3), 125-138 (2008)

17. Alberto, B.M. and Fernando, L.L. A firm-level analysis of determinants of ICT adoption in Spain. technovation, 27, 352-366 (2007)

18. Sharma, M.K. and Bhagwat, R. Practice of informati on systems, an evidence from select Indian SMEs. Journal of Manufacturing Technology, 17: 199-223 (2006)

19. Fink, D. and Disterer, G. International case studies: To what extent is ICT infused into the operations of SMEs. Journal Enterprise Information, 19: 608-624 (2006)

20. Analoui, F. \& Karami, A. Strategic management. in Small and Medium Enterprises. Thomson Learning 2003 (2003)

21. Namasivayam, K., Enz, C. A., \& Siguaw, J. A. How wired are we? Selection and use of new technology in U.S. hotels. The Cornell Hotel and Restaurant Administration Quarterly, 41, 40-48 (2000)

22. Barney, J. Firm resources and sustained competitive advantage. Journal of Management, 17, 99-120 (1991)
23. Drew, S. (2003). Strategic uses of e-commerce by SMEs in the East of England. European Management Journal, 21(1), 79-88.

24. OECD. Organizational change and firm performance. DSTI/DOC, 14 (Paris). (2002)

25. Porter, M. E., \& Kramer, M. R. The competitive advantage of corporate philanthropy. Harvard Business Review, 80(12), 56-68 (2002)

26. Levy M., Powell P., \& Yetton, P. SMEs: Aligning IS and the strategic context. Journal of Information Technology, 16, 133-144 (2001)

27. Chen, Y., and B. Hu. Internationalization of the RMB: An evaluation framework. Economic and Political Studies 1(1), 5-20 (2013)

28. George, D. \& Mallery, P. SPSS for Windows Step by Step: A simple guide and reference $\left(4^{\text {th }}\right.$ ed. $)$. Boston: Allyn \& Bacon (2003)

29. Norasmah, H.O. \& Salmah, I. Kecenderungan terhadap pemilihan kerjaya keusahawanan mengikut persepsi peserta skim usahawan siswa. Jurnal Teknologi, 56, 47-63 (2011) 